\title{
Elimination of metal interference in the determination of fluoride ion by non- suppressor type ion chromatography
}

\begin{abstract}
A simple method has been developed to eliminate metal interferences in the ionchromatographic determination of fluoride ion in aqueous solutions. Negative interferences become appreciable on $0.2-\mathrm{mM} \mathrm{F}$ at 0.01 to $0.02 \mathrm{mM}$ of $\mathrm{Al}(\mathrm{III}), \mathrm{Ce}(\mathrm{IV}), \mathrm{La}$ (III), Y(III), $\mathrm{Ce}$ (III) and $\mathrm{Pb}$ (II); and at $0.25 \mathrm{mM}$ of $\mathrm{Ca}$ (II). The interference from $\mathrm{Cd}$ (II), $\mathrm{Co}$ (II), $\mathrm{Fe}$ (II) and $\mathrm{Ni}$ (II) is insignificant at Oे 5.0-mM metal for 5.0-mM F-. By alkalifying F- solutions at pH 12.3 , the metal interference can be eliminated up to the concentrations of $0.25-\mathrm{mM} \mathrm{Al}$ (III), $\mathrm{La}(\mathrm{III})$ and $\mathrm{Y}(\mathrm{III}) ; 1.0-\mathrm{mM} \mathrm{Ce}(\mathrm{IV}) ; 2.5-\mathrm{mM} \mathrm{Ce}(\mathrm{III})$; and 5.0-mM Pb(II), Cd(II), Co(II), $\mathrm{Fe}$ (II) and $\mathrm{Ni}(\mathrm{II})$. The $\mathrm{Ca}$ (II) interference cannot be eliminated. The pretreatment enables determination of 0.2 - to $5.0-\mathrm{mM} \mathrm{F}$ - in presence of $0.25-\mathrm{mM} \mathrm{Al}(\mathrm{III})$ or $\mathrm{La}(\mathrm{III})$ with coefficient-of-variations of 1.99 to $6.20 \%$.
\end{abstract}

Keyword: Alkali pretreatment; Fluoride analysis; Ion chromatography; Metal interference 